\title{
FACTORS CONTRIBUTING TO THE SUCCESSFUL BUSINESS OF STREET MARKET FOOD VENDORS
}

\section{Nur Atiqah Rochin Demong*}

Department of Technology and Supply Chain Management Studies, Faculty of Business and Management Universiti Teknologi MARA Caw Selangor, Kampus Puncak Alam, 42300

Malaysia

rochin@uitm.edu.my

\section{Erne Suzila Kassim}

Department of Technology and Supply Chain Management Studies, Faculty of Business and Management Universiti Teknologi MARA Caw Selangor, Kampus Puncak Alam, 42300

Malaysia

ernekassim@uitm.edu.my

\section{Noor'ain Mohamad Yunus}

Department of International Business and Management Studies, Faculty of Business and Management Universiti Teknologi MARA Caw Selangor, Kampus Puncak Alam, 42300

Malaysia

noorainyunus@uitm.edu.my

\section{Melissa Shahrom}

Department of Technology and Supply Chain Management Studies, Faculty of Business and Management Universiti Teknologi MARA Caw Selangor, Kampus Puncak Alam, 42300

Malaysia

melissa@uitm.edu.my

\section{Sri Fatiany Abdul Kader Jailani}

Department of Technology and Supply Chain Management Studies, Faculty of Business and Management Universiti Teknologi MARA Caw Selangor, Kampus Puncak Alam, 42300

Malaysia

fatiany@uitm.edu.my

*Corresponding author's Email: rochin@uitm.edu.my

Peer-review under responsibility of 4th Asia International Multidisciplinary Conference 2020 Scientific Committee http://connectingasia.org/scientific-committee/ (C) 2020 Published by Readers Insight Publisher, lat 306 Savoy Residencia, Block 3 F11/1,44000 Islamabad. Pakistan, editor@readersinsight.net

This is an open access article under the CC BY-NC-ND license (http://creativecommons.org/licenses/by-nc-nd/4.0/). 


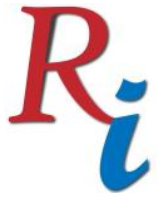

\section{Asia Proceedings of Social Sciences (APSS) \\ www.readersinsight.net/APSS}

\section{Abstract}

Micro-entrepreneurship (ME) plays an important role in the country's economic development in generating urban informal economy. Street market business can be classified as microentrepreneurship which in most cases the business has no employees besides the owner (Jayachandran, 2020). High levels of unemployment and economic crisis led to the increasing number of street market vendors as a means of survival and its ability to provide basic needs at affordable prices to the surrounding communities. This paper presents an analysis of the success factors contributing to the street market food vendors in selected street markets in Malaysia. We highlight and identify some key factors that positively affect their sales revenue. A qualitative approach using focus group discussion method has been used to gain an in-depth understanding of success factors. A mini focus group discussion and exploration of issues were conducted. According to Sherman (2019), business success was measured based on individual, environmental or organizational factors and government support which can be divided into internal and external factors. We group those factors into controllable and uncontrollable factors. The results indicate that individual factors, specifically business experience, is an important success factor that positively affects sales revenue. The paper also comes to the conclusion that individual, environmental and organizational factors were found positively and significantly related to the success of street market food business.

\section{Research Highlights}

1. Street markets which are influenced by informal work and dominantly represented by the bottom group of the social economy population exist because of the urban landscape and metropolitan architecture, accessibility and serve as a cultural revival.

2. People's changing lifestyle and the Internet as the disruptive technology have created challenges to street market vendors, which majority of them are micro-entrepreneurs.

3. Individual, environmental and organizational factors are related to the success of street market food business with business experience as an important determinant of sales revenue. 


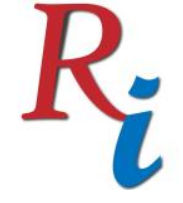

Asia Proceedings of Social Sciences

(APSS)

www.readersinsight.net/APSS

\section{Graphical Abstract}

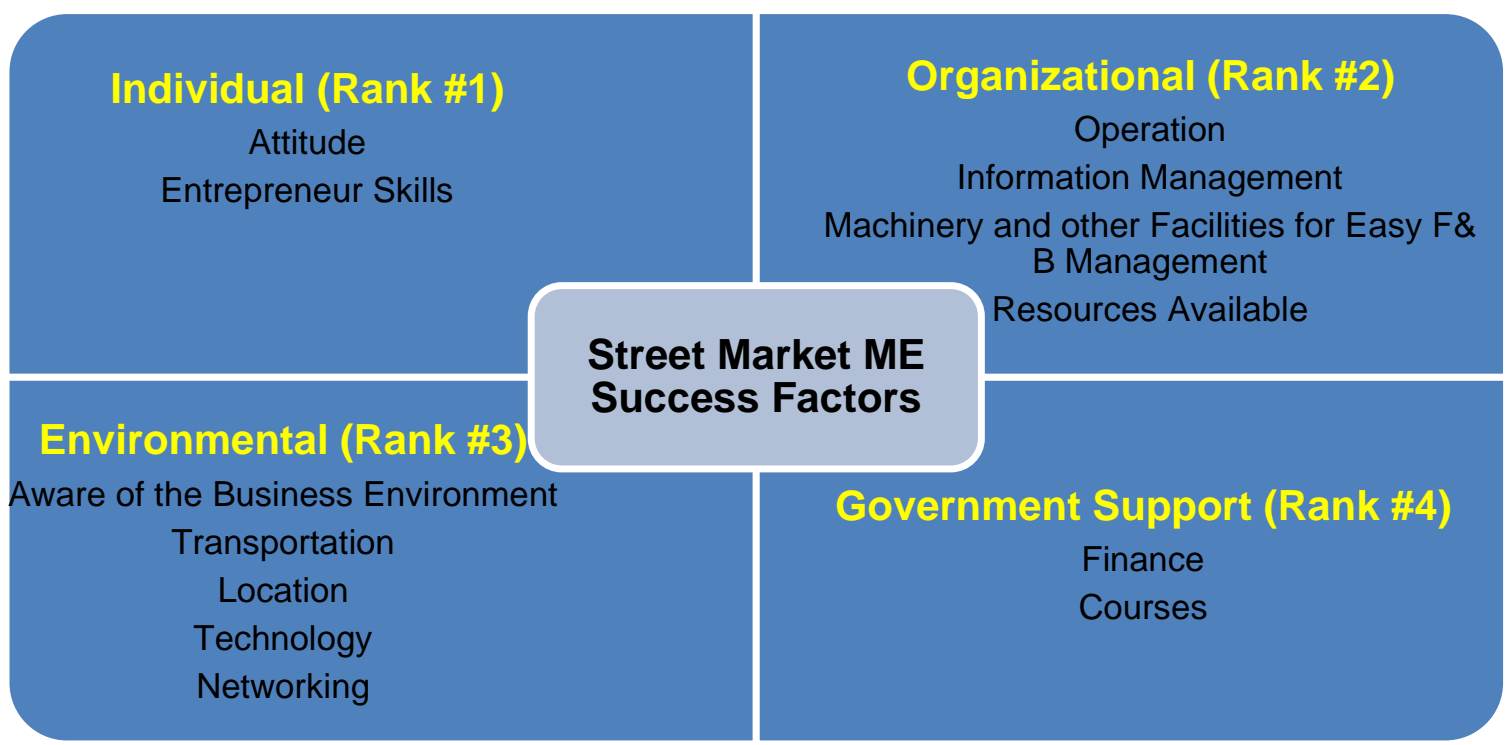

\section{Research Objectives}

The research aims at assessing the motivations and success factors of selected food street market vendors in Malaysia. This research is exploratory in nature as its aim is to explore the individual, organisational and environmental elements that ascertain the food street market vendor's business success. Identifying the factors and understanding their success would help to build a resilience business within the fast changing consumer demand and lifestyle.

\section{Methodology}

A mini focus group study was conducted using the K-J Method that allows for screening and organizing numerous ideas into groups, grounded on their meaning and helping resolve problems efficiently (Anonymous, 2020). The questions focused on the motivation behind entering into the venture (perceived) success factors and challenges being faced by them. Initially, several open-ended questions were utilized to define the responses from the participants. A set of criteria was established to guide the researchers during the selection process to ensure that those involved in the mini focus group study can represent the population. The criteria include (1) successful with more than one-year experience; (2) represent food vendors of a street market in the local area; and (3) have received assistance and support to run the business. During the focus group meeting, the participants were asked to think and list down the business success factors contributing to their business, discuss these 


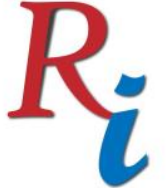

\section{Asia Proceedings of Social Sciences (APSS) \\ www.readersinsight.net/APSS}

factors in groups to reach mutual agreement on the grouping elements. Further discussion was on identifying the placement of the factors into the four quadrants of important versus not important and within the control versus beyond control.

\section{Results}

Street Market Micro-entrepreneurs Success Factors

\begin{tabular}{|c|c|c|c|}
\hline \multicolumn{2}{|c|}{ Within Control } & \multicolumn{2}{|c|}{ Beyond Control } \\
\hline Important & Not Important & Important & Not Important \\
\hline Individual (Rank \#1) & Individual & Individual & Individual \\
\hline 1. Attitude & 1. Online business & 1. Learn from mistakes & 1. Awards \\
\hline 2. Entrepreneur skills & encouragement & 2. Learn from experience & 2. Age \\
\hline & 2. Lifelong & 3. Family conditions & \\
\hline Organizational (Rank & learning & 4. Technology & Environmental \\
\hline \#2) & & advancement (online & 1. License issuance \\
\hline 1. Operation & Environmental & business) & 2. Motivation \\
\hline $\begin{array}{l}\text { 2. Information } \\
\text { management }\end{array}$ & $\begin{array}{l}\text { 1. Product } \\
\text { improvement }\end{array}$ & 5. Health condition & $\begin{array}{l}\text { 3. Support from peers } \\
\text { and neighbors }\end{array}$ \\
\hline 3. Machinery and other & (innovation) & Environmental & \\
\hline facilities for easy $F \&$ & 2. Product quality & 1. Accounting systems & Organizational \\
\hline B management & & 2. Taxation & 1. Audit and \\
\hline 4. Resources available & Organizational & 3. Provision of courses and & classification \\
\hline Environmental (Rank & $\begin{array}{l}\text { 1. Business partner } \\
\text { sharing }\end{array}$ & $\begin{array}{l}\text { seminars (training and } \\
\text { development) }\end{array}$ & Government Support \\
\hline \#3) & & 4. Competition & 1. Government \\
\hline 1. Aware of the & Government & 5. Weather & subsidies \\
\hline business environment & Support & 6. Family support & 2. Political changes \\
\hline 2. Transportation & 1. Compound & & Government \\
\hline 3. Location & 2. Price control & Organizational & support \\
\hline 4. Technology & & 1. Sales & License issuance \\
\hline 5. Networking & & 2. Profit & by Local \\
\hline & & 3. Capital & Municipal \\
\hline $\begin{array}{l}\text { Government Support } \\
\text { (Rank \#4) }\end{array}$ & & 4. Resources supplies & \\
\hline 1. Finance & & Government Support & \\
\hline 2. Courses & & $\begin{array}{ll}\text { 1. } & \begin{array}{l}\text { Business guidelines/ } \\
\text { regulation (government } \\
\text { policy) }\end{array} \\
\text { 2. Financial assistance } \\
\text { 3. }\end{array}$ & \\
\hline
\end{tabular}

\section{Findings}

The findings discovered that individual factors are the most important factor followed by organizational factors as the second and government supports and environment factor respectively. For individual factors, attitude (hardworking, smile, deep interest, survival instinct, focus and mentality) and skills (communication and marketing) ranked as the most 


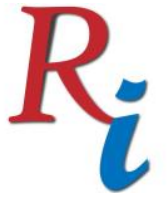

\section{Asia Proceedings of Social Sciences (APSS) \\ www.readersinsight.net/APSS}

important factor. Operations such as running business daily, joint event, early preparation and enough workforces ranked as the second success factor. Aware of the business environment, transportation, location, technology and networking ranked as the third important and government support and courses provided ranked as the fourth factor contributing to the business success.

\section{Acknowledgement}

The authors would like to acknowledge Universiti Teknologi MARA, Cawangan Selangor, Puncak Alam Campus for funding the study via Dana UCS (600-UITMSEL (PI. 5/4) (032/2018). We also acknowledge the Faculty of Business and Management for supporting the research work.

\section{References}

Anonymous. (2020). K-J Method.

Jayachandran, S. (2020). Microentrepreneurship in developing countries. The national bureau of economic research. Massachusetts, Cambridge. URL: http://faculty.wcas.northwestern.edu/ sjv340/microentrepreneurs.pdf

Sherman, F. (2019). What are internal and external environment factors that affect business? March 8, 2019. Hearst Newspapers. Url: https://smallbusiness.chron.com/internalexternal-environmental-factors-affect-business-69474.html

Author's Biography

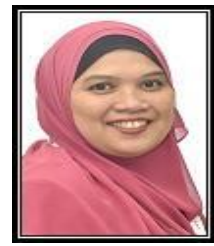

Nur Atiqah Rochin Demong is a final-year PhD student at the University of Technology Sydney. She received a bachelor's degree in Economics from Universiti Utara Malaysia and a master's degree in Information Technology from Universiti Utara Malaysia, Malaysia. Her current field placement is with the Universiti Teknologi MARA. She is interested in big data environments, information systems management, databases, multidimensional databases, data warehouses, e-commerce and digital technologies.

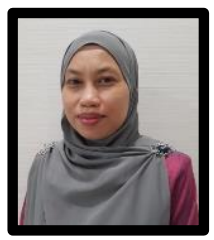

Erne Suzila Kassim is an associate professor at the business faculty. Erne received her Bachelor Degree from Indiana University in Bloomington, USA, majoring in Economics and Sociology, MSc and PhD in IT, mainly specializing in digital innovations. She has been awarded with research grants for projects in e-learning, green IT, e-commerce and IT for micro-enterprises. Her research interests include social networking, social innovation and value creation. 


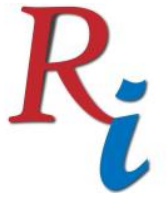

\section{Asia Proceedings of Social Sciences (APSS) \\ www.readersinsight.net/APSS}

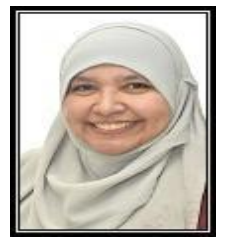

Noor'Ain Mohamad Yunus is a Senior Lecturer at the Faculty of Business and Management, UiTM Puncak Alam, Selangor, Malaysia. She received her PhD in Business Administration from International Islamic University Malaysia in 2018. Her current field placement is with the Department of International Business and Management Studies. She is interested in research related to population ageing, healthcare utilisation, health informatics, management and healthcare management.

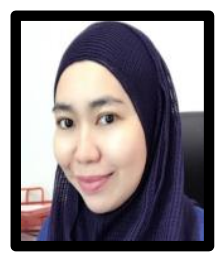

Melissa Shahrom is a Senior Lecturer at the Faculty of Business and Management, UiTM Selangor, Malaysia. She received her PhD Engineering from University of Melbourne, Australia in 2018. Her research and teaching focus on information security and privacy, wayfinding and navigation, social sensing and persuasive technology. She is now a member of the International Association of Privacy Professionals (IAPP) and Innovation Management Research Interest Group in UiTM, Malaysia.

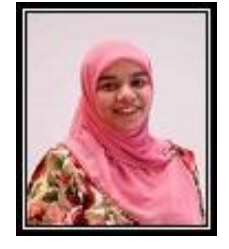

Sri Fatiany Abdul Kader Jailani is a final-year PhD student at the International Islamic University, Malaysia. She received a bachelor's degree and a master's degree in Information Technology from Universiti Teknologi MARA Malaysia. Her current field placement is with the Universiti Teknologi MARA. Her research area includes information technology, sustainability and social networking. 